\title{
DIFERENTES ASPECTOS CLÍNICOS DO PAPILOMA ORAL
}

Andressa Marafon SEMPREBOM, Roberta Targa STRAMANDINOLI, Fábio Alves IZIDORO, Ana Claudia Santos de Azevedo IZIDORO, Lúcia Fátima de Castro ÁVILA

O papilomavírus (HPV) é um DNA vírus que infecta ceratinócitos da pele ou das mucosas, sendo freqüente na região ano-genital e raro na mucosa oral. Sua implantação oral pode ser por auto-inoculação ou pelo contato oro-sexual. Em lesões bucais o HPV-6 e HPV11 têm sido associados a um baixo risco de malignidade, enquanto o HPV-16 e HPV-18 são relacionados a neoplasias malignas. Várias lesões bucais são associadas ao HPV. Dentre as benignas, citam-se: papiloma, verruga vulgar, condiloma acuminado e hiperplasia epitelial focal. Em relação às malignas, destacam-se os carcinomas epidermóide e verrucoso. $\mathrm{O}$ diagnóstico de infecção por HPV é baseado em aspectos clínicos e histopatológicos, como hiperceratose, coilocitose, disceratose, papilomatose e acantose. O papiloma oral é uma proliferação benigna do epitélio escamoso estratificado, sendo os locais mais comumente afetados a língua e o palato mole. A lesão apresenta-se normalmente como um nódulo flácido, exofítico, pedunculado, com numerosas projeções semelhantes a dedos na superfície, que the dão aparência de couve-flor. Podem apresentar coloração branca, vermelho claro ou semelhante a da mucosa normal, dependendo da ceratinização da superfície. Neste painel serão apresentados diferentes aspectos clínicos do papiloma oral e seu tratamento, auxiliando o cirurgião-dentista no diagnóstico e resolução clínica desta lesão. 